\title{
Contemporaneous, localized, basal ice-flow variations: implications for bedrock erosion and the origin of $p$-forms
}

\author{
Brige R. Rea, ${ }^{1}$ David J. A. Evans, ${ }^{2}$ Tom S. Dixon, ${ }^{3}$ W. Brian Whalley ${ }^{3}$ \\ ${ }^{1}$ Department of Earth Sciences, Cardiff University, Cardiff CF10 3YE, Wales \\ ${ }^{2}$ Department of Geography and Topographic Science, University of Glasgow, Glasgow G12 8QO, Scotland \\ ${ }^{3}$ School of Geography, Queen's University Belfast, Belfast BT 7 1NN, Northern Ireland
}

\begin{abstract}
A detailed study of a proglacial bedrock site and a subglacial cavity of an outlet of Øksfjordjøkelen, Norway, is presented together with observations from the foreland of Konowbreen, Spitsbergen. Striation directions and subglacial observations indicate that local ice-flow paths were highly variable, deviating at angles of approximately $90^{\circ}$ from the main ice-flow direction. Stepped bedrock topography appears conducive to the production of highly variable ice-flow paths, because the high bed roughness creates a locally variable stress regime within the ice, including low-pressure, lee-side areas into which ice can flow. If ice flow is sustained along a specific path and the ice contains debris, then abrasion should produce an erosional bedform. Models are proposed whereby locally variable ice-flow patterns could produce erosional bedforms, which would be described as p-forms, purely through mechanical abrasion.
\end{abstract}

\section{INTRODUGTION}

Boulton (1974) argued that basal ice will have complex flow patterns as a direct result of bedrock roughness elements and the resultant stress variations they induced within the ice. Recent geochemical investigations of Greenland ice cores have revealed that complex mixing patterns occur in the lower layers of ice sheets (Souchez and others, 1995, 1998). Finite-element modelling of ice flow over undulating bedrock has also shown extremely variable velocity profiles (Gudmundsson, 1997). This paper presents detailed mapping and interpretations of complex striation patterns on deglaciated bedrock exposures and draws on contemporary subglacial observations which relate directly to basal ice mixing and complex ice-flow paths. Striation patterns are presented which imply that, locally, basal ice is moving in more than one direction contemporaneously. Such observations are not unique and there have been other reports of such highly variable basal ice-flow patterns mapped from bedrock outcrops in deglaciated areas (Sheldon, 1926; Demorest, 1938; Edleman, 1949; Gjessing, 1966; Gray and Lowe, 1982). Contemporary subglacial process observations presented here provide direct analogues for the observed proglacial striation patterns. Variable ice-flow patterns have direct implications for the erosion of bedrock and the production of p-forms (Dahl, 1965), a link suggested previously by Boulton (1974). Dahl (1965) introduced the term p-form to describe "plastically sculptured forms" of subglacial erosion found on bedrock surfaces. These features typically have "strongly marked relief", "often have sharp edges and a beautifully curved course" and include forms such as potholes and Sichelwannen (sickle-troughs). Several theories have been proposed to explain the origin of these forms, but a recent explanation invoking erosion by subglacial meltwater origin has become prevalent (e.g. Shaw, 1988; Kor and others, 1991). Detailed observations of highly variable basal ice flow from proglacial and subglacial sites at Øksfjordjøkelen, North Norway, and Konowbreen, St Jonsfjorden, Spitsbergen, are used to construct models explaining the origin and evolution of mechanically eroded p-forms.

\section{2. ØKSFJORDJØKELEN}

Basal ice-flow patterns can be reconstructed from striations on deglaciated bedrock and from subglacial observations. Øksfjordjøkelen has a number of plateau-terminating outlet glaciers, one of which provides extensive subglacial access to cavities near the ice margin, in addition to an extensive proglacial area that has been progressively deglaciated since the end of the Little Ice Age (LIA). This makes it an ideal location for studying subglacial erosion processes.

\subsection{Field site}

"Camp Glacier" (unofficial name) is a small, plateau-terminating outlet of Øksfjordjøkelen, a plateau icefield located on the Bergsfjord peninsula, North Norway $\left(70^{\circ} 10^{\prime} \mathrm{N}, 22^{\circ} 00^{\prime} \mathrm{E}\right)$. The snout of "Camp Glacier" is presently warm-based and sliding (Rea and Whalley, 1994). Bedrock in the vicinity is layered, and undifferentiated gabbros formed during the Finnmarkian orogenic stage (550-500 Ma) (Sturt and others, 1978). Three joint sets are present, two sub-vertical and one sub-horizontal, and are preglacial in origin. The foreland rises in a series of large rock bars, with some of the lee-side faces reaching $10 \mathrm{~m}$ in height, forming a large subglacial cavity beneath the snout (Rea and Whalley, 1994).

Subglacial quarrying during the LIA advance and subsequent retreat has produced a series of rock steps (superimposed on top of the rock bars) whose lee-side faces strike 
approximately perpendicular to the LIA ice-flow direction (Rea and Whalley, 1996). As a consequence of basal sliding over these rock bars and steps, lee-side cavities appear to have been present during and since the LIA, based on the identification of non-striated bedrock areas, lee-side cavity deposits and subglacial observations. Pressure fluctuations (high on stoss sides and low on lee sides) in basal ice associated with sliding over these rock steps are favourable for the initiation and maintenance of highly variable basal ice flows (Boulton, 1974). Although there is debris in the basal ice, no evidence has been found of even a patchy till layer.

\subsection{Field evidence}

The main focus of investigation is a rock step which shows evidence of highly variable basal ice flow. In this section a detailed description is given of the rock step and the ice-flow patterns displayed by the striations. Further supporting observations from the subglacial cavity are presented later.

The rock step lies on the east side of the foreland on one of the large rock bars (Fig. 1). A contour map of the rock step is shown in Figure 2, with the various ice-flow directions indicated. Figure 3 shows the lee-side face of the step with ice-flow directions again marked. The main flow direction (taken to indicate the mean stoss-side basal ice-flow direction) over the top of the step is $\sim 165^{\circ}$. The lee-side face is jointcontrolled and strikes at $\sim 75^{\circ}$, forming an angle of $\sim 90^{\circ}$ with the main flow direction.

The stoss surface is planar (controlled by the sub-horizontal joint set) on the east side of the outcrop with only a small lee-side quarried face (vertical drop $\sim 0.5 \mathrm{~m}$ ). This lee-side face makes up one side of a joint-controlled channel which runs approximately northeast--southwest across the stoss surface on the east of Figures 2 and 3. Fluted upper surfaces of precipitates and striation directions have been used to identify the direction of ice flow into and along this channel. The precipitates appear to have formed at ice/bed separation points (Hallet, 1976), and exhibit a fluted upper surface, indicating the direction of ice movement. Striations show ice movement across the stoss surface on a bearing of $\sim 165^{\circ}$. Basal ice deformed into and then moved along the channel on a bearing of $\sim 255^{\circ}$, perpendicular to the main flow direction. The precipitates on the channel sides have flutes which are flow-parallel on their upper surface, indicating ice flow down into and along the channel (Fig. 4). Striation directions

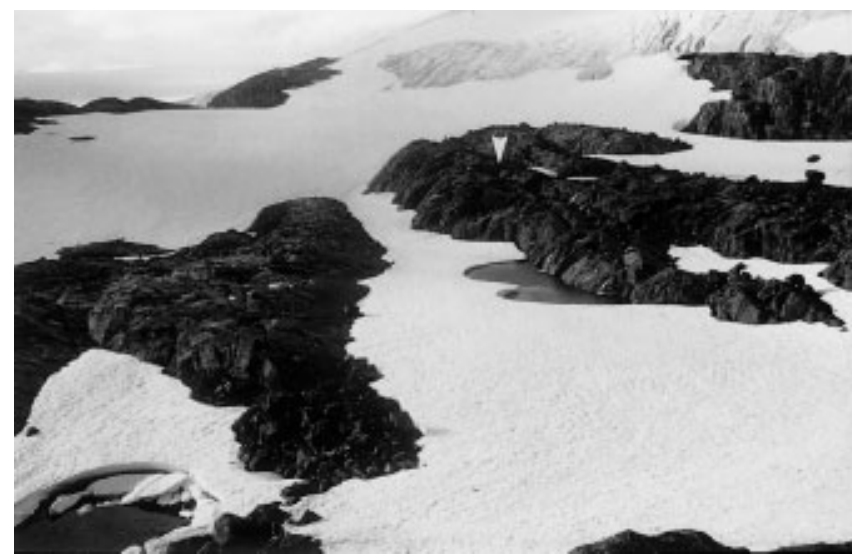

Fig. 1. The foreland of "Camp Glacier", showing high bed roughness and location of the rock step (white arrow). Distance from the glacier snout (top right) to the pool (bottom left) is approximately $250 \mathrm{~m}$.

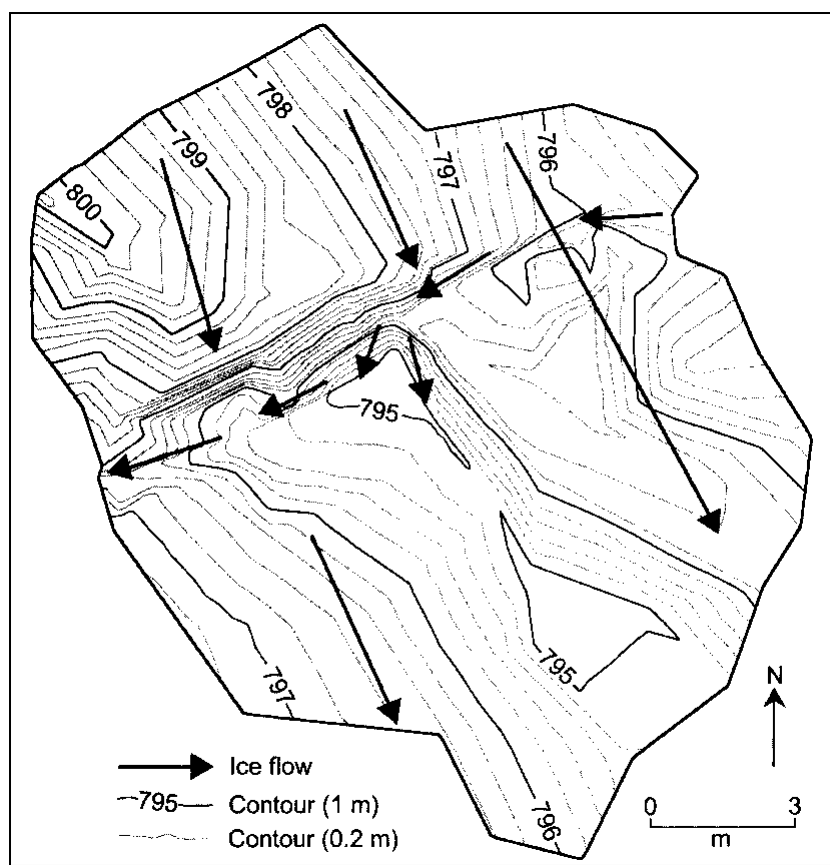

Fig. 2. Contour map (in m a.s.l., surveyed using a total station theodolite) of the rock step in front of "Camp Glacier", showing the ice-flow directions.

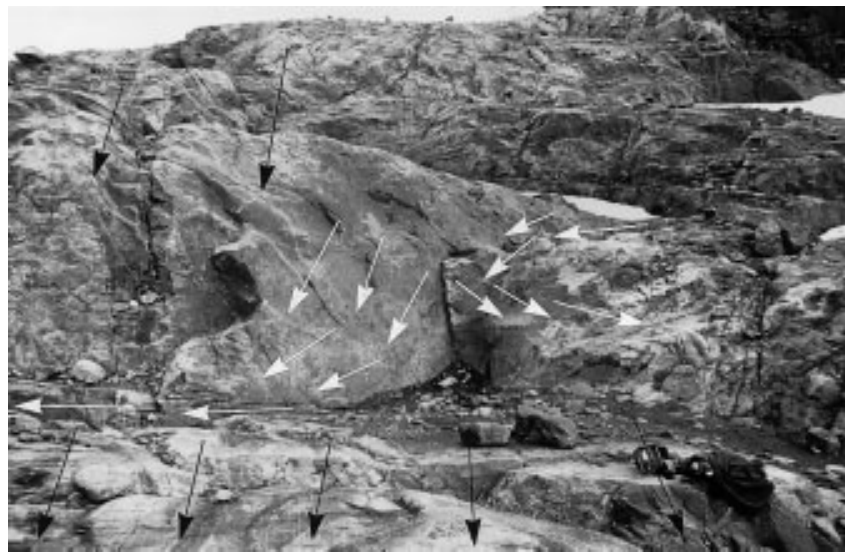

Fig. 3. A view of the central portion of the rock step at "Camp Glacier" shown in Figure 2. The main flow direction is indicated by the black lines, and the lower basal ice flow direction is shown in white. For scale see Figure 2 and the rucksack (right foreground).

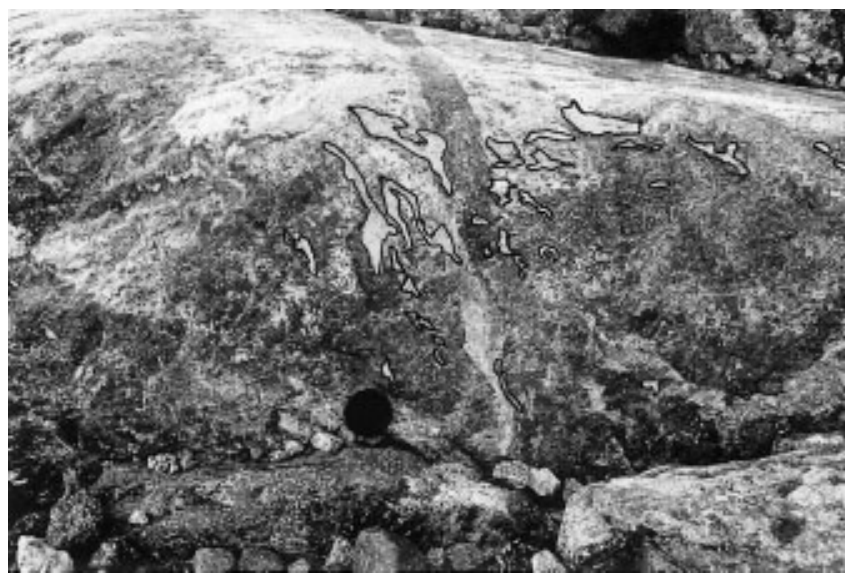

Fig. 4. Channel wall with precipitates at "Camp Glacier" (outlined in black), indicating that ice flowed down into and along the channel. 
indicate that ice flowed along the channel to a point where it was drawn around to rejoin the main flow direction on a bearing of $\sim 165^{\circ}$ (Figs 2 and 3). Striations within the channel are much finer (narrower and shallower) than those typically found on stoss surfaces.

Striations indicate further complex ice-flow patterns over the top of the large lee-side face on the west side of Figures 2 and 3. Striations deviate slightly to the west as ice moves over the crest of the rock step where abraded facets are developed. On the steepest parts of the lee-side face, fine striations sweep down and, at the base of the face, curve towards the west. Further along, a channel forms and runs the remaining length of the face (Figs 2 and 3). The channel sides are finely striated and also have flow-parallel fluted precipitates, indicating ice movement along the channel on a bearing of $\sim 255^{\circ}$, towards an exit on the west side of the rock step. The detailed descriptions above and Figures 2 and 3 show that ice flow over this rock step involved a number of interconnected directions of ice movement.

Approximately $4 \mathrm{~m}$ down-glacier from the foot of the leeside face, described in Figures 2 and 3, a shallow sinuous channel occurs in the middle of an up-glacier-dipping stoss surface. The channel follows a joint, widens in a down-glacier direction (Fig. 5) and has rough sides and base. Close inspection showed fine striations along the walls of the channel, indicating ice movement along it, guided by the local smallscale topography.

Observations over a number of years in the snout cavity beneath "Camp Glacier" have allowed investigation of the progression of bedrock erosion. Figure $6 \mathrm{a}$ and $\mathrm{b}$ illustrate $\mathrm{a}$ subglacial site near the snout of the glacier below $\sim 5-7 \mathrm{~m}$ of ice. The main flow direction $\left(\sim 180^{\circ}\right)$ is from left to right across the top of the picture, with a lower-level ice flow along a channel, coming towards the camera on a bearing of $\sim 270^{\circ}$. Measurements indicate basal sliding velocities of $5-5.5 \mathrm{~m} \mathrm{a}^{-1}$ for the main flow direction, but velocity markers in the lower ice flow were reincorporated into the main ice flow within the annual repeat measurement period. From its entry point into the cavity, the lower basal ice flow bends around and is observable for about $2 \mathrm{~m}$, after which it is incorporated into the glacier sole. Thus, loss of the markers suggests the lower basal ice flow has a minimum velocity of $2 \mathrm{~m} \mathrm{a}^{-1}$. The lower basal ice flow forms a maximum angle with the main flow direction of approximately $90^{\circ}$. The significance of these subglacial observations is discussed below.

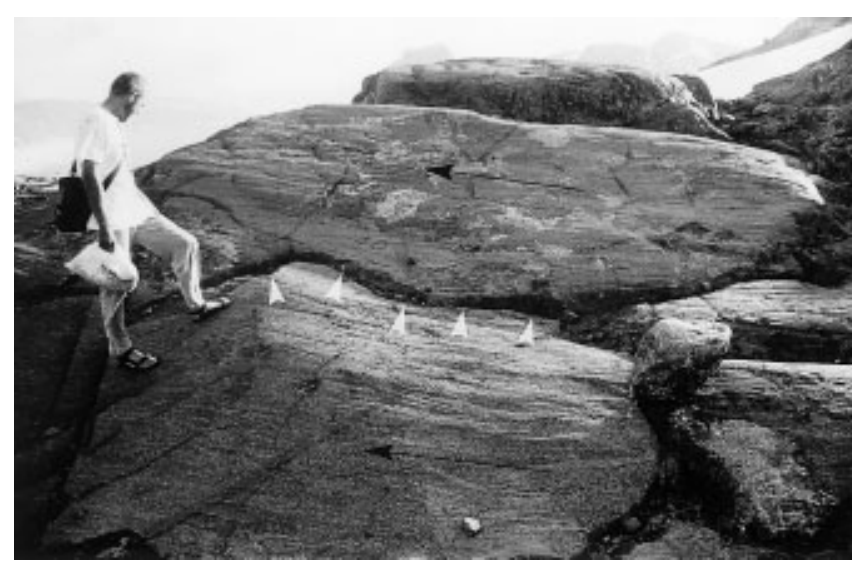

Fig. 5. Foint-controlled sinuous channel at "Camp Glacier" (white arrows), situated on a stoss surface, containing striations. The main flow direction is indicated by the black arrows.

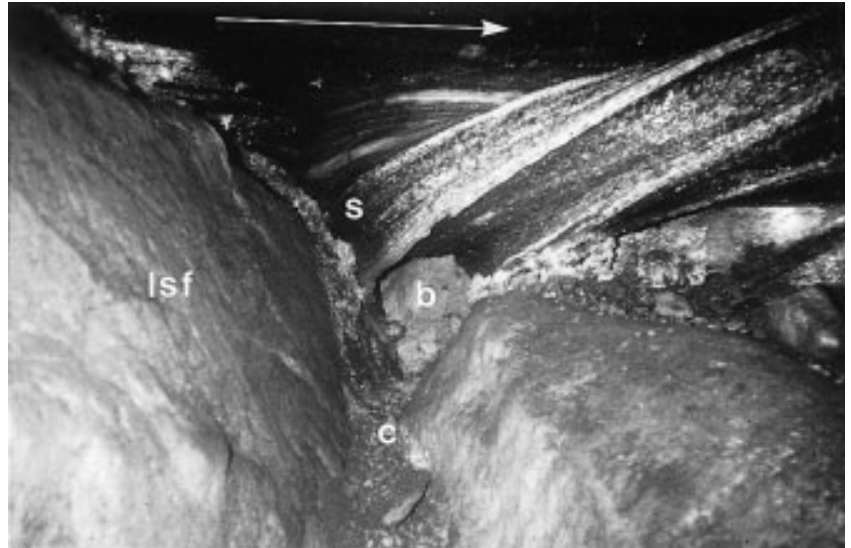

6a

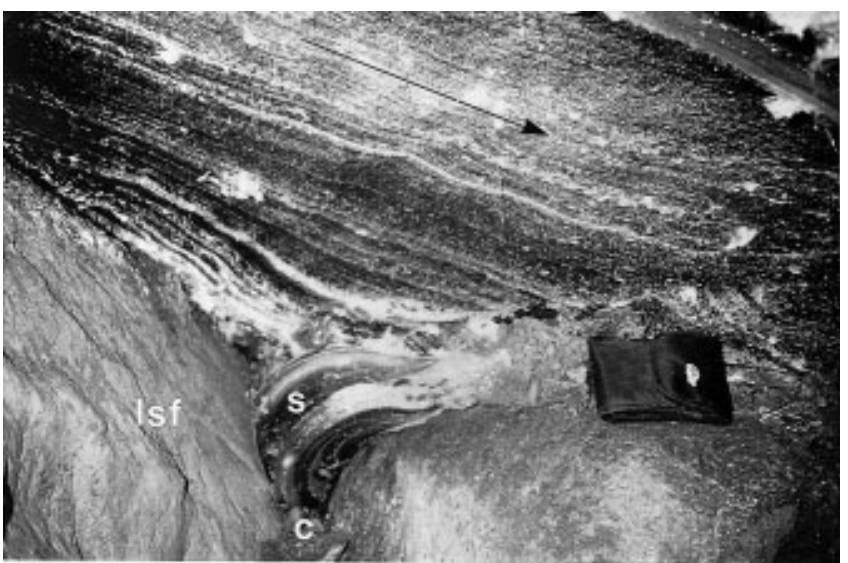

$6 \mathrm{~b}$

Fig. 6. (a) Subglacial site at "Camp Glacier" photographed in 1992, showing locally variable basal ice flow. As the ice leaves the channel it is drawn round by approximately $90^{\circ}$ to rejoin the main flow direction. Note b, the block filling the joint-controlled channel. The main flow direction is indicated by the white arrow; c, joint-controlled channel; lsf, lee-side face; s, lower basal ice flow, initially coming towards the camera. Note wallet (0.1 m long) in (b) for scale. (b) Subglacial site shown in ( a) photographed in 1997. The block has been removed and the lower basal ice flow is now filling the channel. The main flow direction, which forms the roof of the cavity, is indicated by the black arrow; c, joint controlled channel; lsf, lee-side face; s, lower basal ice flow (note wallet for scale).

\subsection{Interpretation}

Two ice-flow directions can be identified from the rock step described in Figures 2 and 3: the main flow direction $\left(\sim 165^{\circ}\right)$ and the lee-side and channel flows $\left(\sim 255^{\circ}\right)$. Striations curve down over lee-side faces and into channels from the main flow direction, offering convincing evidence of the contemporaneous nature of the ice flows. The lee-side and channel flows originate from the main flow direction and are drawn away from it into low-pressure regions, forming localized, high-angled variable ice-flow patterns. It could be argued that the $255^{\circ}$ striations are older, having merely survived subsequent modification in the protected lee-side and channel positions. However, Figure $6 \mathrm{a}$ and b provide evidence from a contemporary subglacial site near the snout of the glacier. Here, there are variable ice-flow directions deviating locally by up to $90^{\circ}$, intimately linked to the bedrock topography. The basal ice-flow pattern shown in Figure $6 \mathrm{a}$ and $\mathrm{b}$ appears to be analogous to the ice-flow directions (reconstructed using striations and fluted surfaces of precipitates) associated with the channel on the east side of Figures 2 and 
3. The Figure 6a photograph was taken in 1992, and the important point to note is the block (b) filling the channel. The block was still in place in summer 1995. Figure 6b shows that by summer 1997 the lower ice flow has filled the channel, indicating removal of the block shown in Figure 6a. It should be noted that the erosion is joint-controlled.

It seems likely that the large lee-side face (Figs 2 and 3) was striated under conditions of low sliding velocity, when ice moved across the bed in contact with the face. The westward swing of the striations, being the result of high basal ice pressures, developed at the foot of the face. Ice was forced westwards along the foot of the face, through the channel and out to rejoin the main ice flow at the western extremity of the rock step. It is also possible that the striations were produced during subglacial block plucking as described by Rea and Whalley (1994).

The location of the channel shown in Figure 5, in the middle of a stoss face, and the rough nature of its sides and bottom suggest that it has not been cut by subglacial fluvial action. Channelized water would drain along a low-pressure route, probably along the lee-side face, and not across the centre of the stoss face where bed-normal stresses would have been greatest and ice/bed contact was complete. The channel forms through fracturing as stresses in the bedrock, produced by the passage of entrained striating clasts, are focused by the joint. Through this mechanism, the joint is gradually widened to form the channel. Striated walls indicate that basal ice with debris inclusions was funnelled along the channel. In the following section we present observations of other erosional bedforms.

\section{KONOWBREEN}

Situations where both subglacial and proglacial observations can be made are ideal for studying subglacial erosion processes, but important information can still be obtained from proglacial observations alone. In this section proglacial observations from Konowbreen $\left(78^{\circ} 33^{\prime} \mathrm{N}, 13^{\circ} 10^{\prime} \mathrm{E}\right)$ are presented.

\subsection{Field site}

The area of foreland investigated has been exposed by glacier recession within the past 30 years (interpreted from Norsk Polarinstitutt, 1988). The marble bedrock appears to be part of the Alkhorn Formation, of Late Proterozoic age (650-540 Ma; Harland, 1997). Undulating bedrock exposures, best described as rock drumlins, are found on the eastern side of the foreland and continue up-glacier beneath the present glacier snout. A thin till cover has been washed clear from the flanks of the rock drumlins and rock outcrops close to sea level, exposing bedrock with a dense pattern of striations.

\subsection{Field evidence}

A number of bedrock exposures which showed evidence of variable ice flow were investigated, the most notable being, a smoothed, erosional p-form located on the sub-vertical flank of a rock drumlin (Fig. 7a). It can be seen that striations trace the main flow direction, right to left, across the photograph. The "headwall" of the p-form is lightly striated by ice flow which has been drawn down the face and deflected slightly upwards (Fig. 7a). The striations become coarser towards the end of the down-glacier extending arm (indicating greater abrasion), and curve around, parallel to the upper bounding edge of the p-form. The "foot" of the p-form is heavily striated and rises up slightly from the base of the headwall.

Observations made on the top of another, adjacent rock drumlin reveal a crude comma form feature with an angular and blocky appearance (Fig. 7b). It is oriented to the main flow direction in a similar manner to the form shown in Figure 7a.
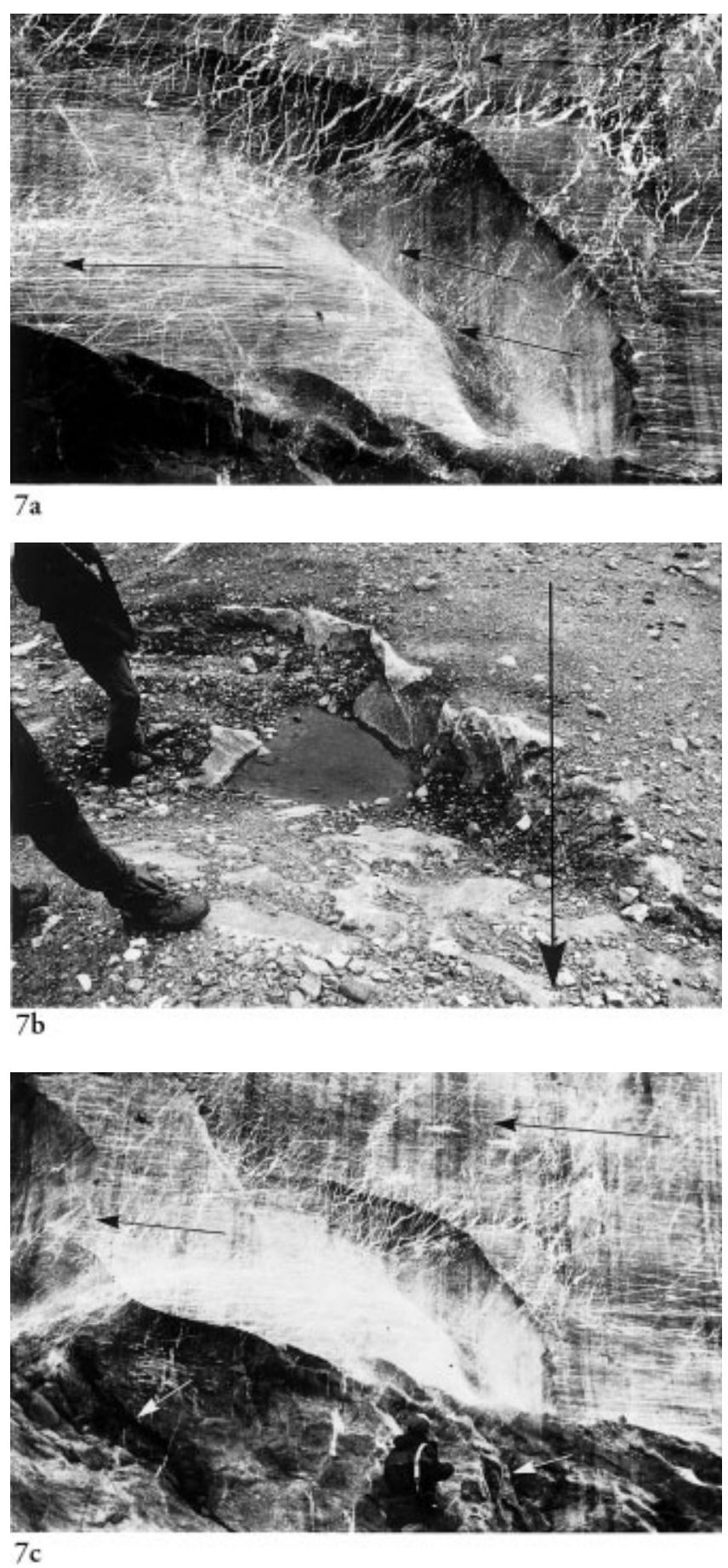

Fig. 7. (a) Comma form situated on the flank of a rock drumlin, on the foreland of Konowbreen. Former ice-flow directions are indicated by the arrows. Note how striations are deflected slightly upwards along the headwall, and curve around the arm of the comma form. For scale see (c). (b) An immature comma form, on the foreland of Konowbreen, with the main flow direction indicated by the black arrow. (c) A widerangled view of the area illustrated in (a), showing the joint planes within the bedrock (white arrows). The main flow direction is indicated by the black arrows. Note person in bottom centre for scale. 


\subsection{Interpretation}

Comma-shaped p-forms have been ascribed to fluvial erosion caused by horseshoe vortices developed in subglacial meltwater (Shaw, 1988; Kor and others, 1991). However, the presence of striations throughout the form shown in Figure $7 \mathrm{a}$ indicates that ice flow has made complete contact with, and eroded rock from, this feature as a result of localized variations in basal ice-flow direction. A close inspection of rock structure and its relationship to the comma form provides valuable information on the possible genesis of the feature. Figure 7c shows a wider view of the p-form and surrounding surfaces. The bedrock has joints (bottom left of Fig. 7c) which run top left to bottom right. Stresses in the bed, produced by the passage of clasts entrained in the basal ice, are focused where joints intersect the surface, and flakes are broken off to initiate headwalls (Fig. 8a) which are gradually enlarged by further quarrying (Fig. 8b). At some point, ice flows down the headwall and makes contact with the up-glacier-dipping surface of the foot (Fig. 8c), locally increasing basal ice pressures. Basal melting is thus enhanced, increasing ice flow towards the bed and the viscous drag imparted on clasts at the ice/bed contact; both leading to increased abrasion (Hallet, 1979, 1981). This explains the coarser striations found on the foot of the comma form. Continued quarrying and abrasion occur in the mature form (Fig. 8d). Headwall configuration is controlled by the orientation of the intersection of the joint (or any plane of weakness) with the bedrock surface. Note also in Figure $7 \mathrm{c}$ the beginnings of a new headwall above and to the left of the end of the large comma form. The striation patterns shown in Figure $7 \mathrm{a}$ and $\mathrm{c}$ indicate that ice moved down in contact with the headwall, was deflected slightly up-

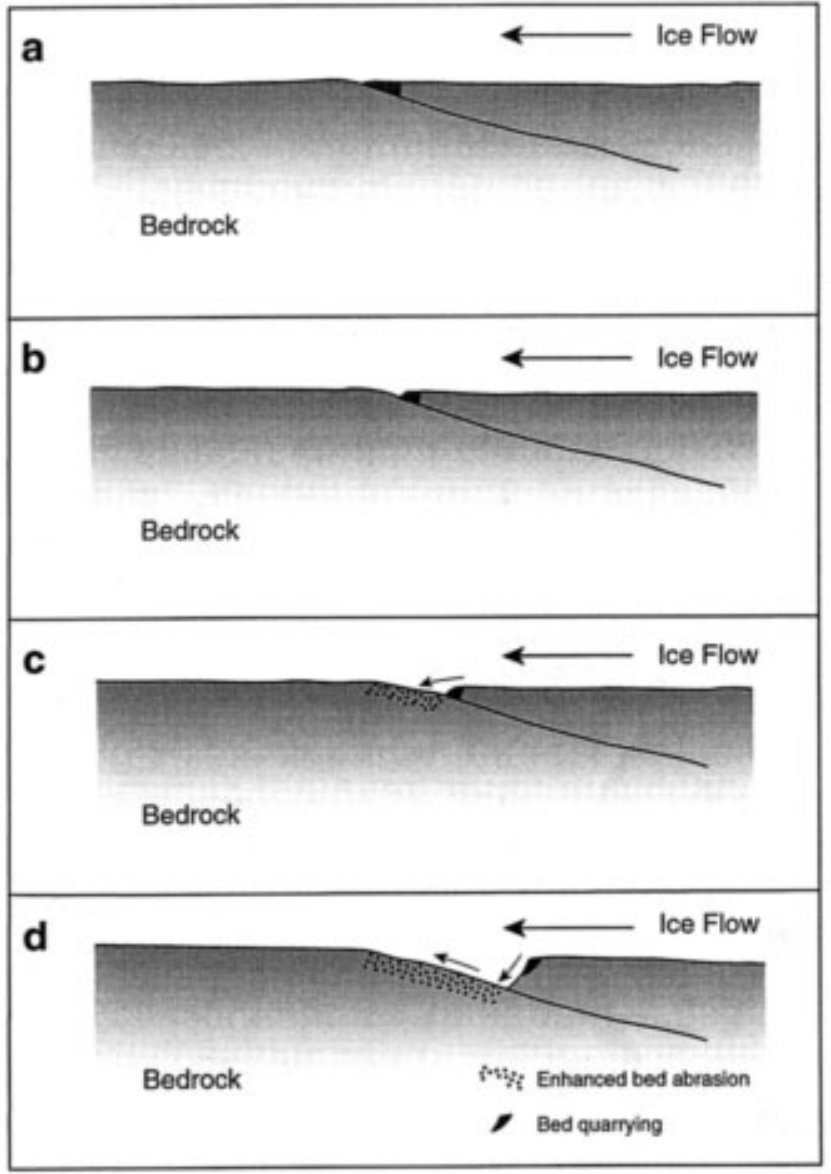

Fig. 8. A model for the production of a comma form by quarrying and abrasion. wards and then curved round following the arm of the comma. Figure $7 \mathrm{~b}$ appears to be an immature comma form, with Figure $7 \mathrm{a}$ and $\mathrm{c}$ representing the mature, smoothed comma form.

\section{DISGUSSION}

\subsection{The evolution of p-forms: hypotheses}

The classification system used here is that of Kor and others (1991) from their comprehensive study of " $s$-forms", although we shall use the more widely accepted term, p-form (Dahl, 1965; Boulton, 1974). The present investigation is concerned with three of the p-forms identified by Kor and others (1991), as defined below:

(i) transverse troughs: relatively straight troughs aligned perpendicular to ice flow, with lengths much greater than widths;

(ii) furrows: flow-parallel linear troughs, much longer than wide also with length much greater than width; and

(iii) comma forms: similar to Sichelwannen (sickle-shaped marks), but with only one arm well developed.

Three eroding media are generally used to explain the formation of p-forms: fast-flowing subglacial water (Ljungner, 1930; Dahl, 1965; Allen, 1971; Gray, 1982; Shaw, 1988; Kor and others, 1991), deforming till (Gjessing, 1966) and debris-rich basal ice (Boulton, 1974; Goldthwait, 1979; Gray, 1982).

Erosion by fast-flowing subglacial water, specifically by the processes of cavitation and corrasion (Shaw, 1988; Kor and others, 1991), has recently taken precedence as the preferred explanation for the formation of $\mathrm{p}$-forms. $\mathrm{p}$-forms containing striations remain problematic in such interpretations. Thus, Shaw (1988) suggested they are generally "a late ornamentation of meltwater erosional forms", produced by ice/ bed contact. Gjessing (1966) proposed the scouring action of a deforming subglacial till to explain the origin of p-forms which contained fine striations and showed no evidence of fluvial faceting. Johnsson (1956) suggested that an ice--water mixture moving by extrusion flow could be responsible for $\mathrm{p}$ forms, but this view has not found significant support.

Direct bed abrasion by debris-rich basal ice has been the least favoured explanation over the past 20-30 years. The most convincing evidence was presented by Boulton (1974) who used observations of debris-rich basal ice "streaming" around obstacles to explain concentration of debris as linear elements within basal ice. Given sufficient time, bed erosion would progress more rapidly beneath these debris-rich regions, and so grooves would be cut into the bed. It was also suggested by Boulton (1974) that lodged boulders or hard bedrock areas would cause divergence of basal ice around their flanks, producing two debris-rich ice streams extending down-glacier. The subsequent erosion pattern in the bed would form a Sichelwannen.

\subsection{Relevance of the observations to $p$-form formation and development}

The observations presented above from Øksfjordjøkelen provide convincing evidence that ice can deviate by up to $90^{\circ}$ to the main flow direction, possibly, but not necessarily, within channels. These directionally highly variable "secondary" ice flows occur in the base of the glacier (Figs 2 and 3) and can erode along lines of bedrock weakness (Fig. $6 \mathrm{a}$ and b) to produce channels. Providing the ice flowing along the channel is 
debris-charged, abrasion will occur, and given sufficient time it should produce a smooth feature. Such a channel matches the transverse trough form described by Kor and others (1991).

Figure 5 shows a shallow, sinuous, stoss-side channel. Ice flow would be drawn into and along the channel and, if charged with debris, would erode, widening and smoothing the feature. Thus, it has the potential to develop into either a curved or winding channel (Dahl, 1965). The channel would resemble a furrow p-form described by Kor and others (1991) produced entirely by basal ice erosion.

The observations presented from the foreland of Konowbreen indicate that ice can conform to and abrade the surface of a comma p-form due to deviations in the local ice-flow direction. The deep striations on the foot suggest that mechanical erosion has a more significant formative role than simply the "late ornamentation" suggested by Shaw (1988). Here, a model has been proposed which accounts for the quarrying of a headwall, heavy abrasion of the foot and smoothing of the form (Fig. 8). Thus, a comma p-form could be produced entirely by mechanical erosion at the ice/bed interface.

No evidence has been found for even a patchy deforming till layer at the bed of Øksfjordjøkelen. All observations indicate that abrasion is accomplished by debris-rich ice sliding over bedrock. At Konowbreen there is evidence of a deforming till layer being present over parts of the bed (D. J. A. Evans, B. R. Rea and D. I. Benn, http://ggg.qub.ac. uk/ggg/; rp04/1998). The extensive abrasion on the p-form suggests that if there was a till layer present at the bed, it is likely to have been thin, coupled to the bed and shearing over the bedrock. The model presented in Figure 8 operates most effectively with debris-rich ice sliding directly over the bed. A deforming till layer might assisting in smoothing the form once it has been eroded out of the bedrock.

\subsection{Identifying ice-sculpted or part ice-sculpted p-forms}

Arguments presented above suggest that, at least in certain circumstances, it is possible for glacier quarrying and abrasion to erode features into bedrock that would be classed as p-forms. It should be made clear that this is not proposed as the only mechanism responsible for the formation of $\mathrm{p}$-forms, and subglacial fluvial processes eroding forms into bedrock are not discounted (e.g. the small-scale flutes and scallops described by Shaw (1988)). The key factor for identifying possible ice-produced forms, similar in origin to those described here, is that they are associated with favourable bedrock structures. In all the examples presented in this study, the p-forms have been eroded along joints in the bedrock. The genesis of p-forms should be evaluated using a number of criteria. First, if their location on the glacier bed is one in which subglacial meltwater is unlikely to have been channelled, they may be mechanical in origin. Second, if the bedrock is massive and the p-forms do not originate from a joint or fracture then fluvial erosion may be the most likely origin (although the ice-streaming action described by Boulton (1974) may be significant). Third, if the striation patterns within and around the p-forms indicate ice has flowed into and along the forms then mechanical ice erosion has modified them. Moreover, even features initiated by fluvial erosion may be accentuated by ice erosion and vice versa. For example, if one assigns a fluvial origin to the comma form shown in Figure $7 \mathrm{a}$ and $\mathrm{b}$, the heavily abraded foot requires intensive, and presumably form-modifying, abrasion by debris-rich ice.

\subsection{Implications for ice dynamics}

The subglacial and proglacial observations from Øksfjordjøkelen both relate to thin $(<100 \mathrm{~m})$ and relatively slow-sliding ice $\left(<5 \mathrm{~m} \mathrm{a}^{-1}\right)$ (Rea, 1994a). In North America, Demorest (1938) made observations on the deglaciated foreland of Clements Glacier where the ice cover had been $<60$ m thick. He described a range of ice-flow patterns including "striae revealing decelerated flow; striae revealing deflections within transverse trenches; striae revealing deflections parallel to oblique steps; and striae revealing eddy-like currents", suggesting that the small-scale bed topography caused complex basal ice-flow patterns. Boulton (1974) described processes occurring beneath $\sim 60 \mathrm{~m}$ of ice at the base of Breidamerkurjökull. Sheldon (1926) described a glacially eroded bedrock channel on the Cornell University campus, New York State, U.S.A., where differential ice movement along divergent paths was recorded. Goldthwait (1979) suggested that fast-moving basal ice streams produced the glacial grooves on Kelleys Island in Lake Erie. Both Sheldon (1926) and Goldthwait (1979) described erosion that occurred beneath the Laurentide ice sheet, so the ice thickness could have been substantial. Edelman (1949) examined erosion forms in an area of southwest Finland formerly covered by the Fennoscandian ice sheet, and described a "secondary" ice movement, oblique to main ice-flow direction, which occurred at the base of a stoss slope. Gray (1982) described a "trench" lying transverse to the main iceflow direction, which contained striations, produced beneath Late Devensian ice, in Snowdonia, North Wales.

The above observations suggest that there is a range of subglacial situations in which highly variable basal ice flows can occur. The one common feature of all the sites mentioned is that the bed is irregular and so can induce rapidly varying stress patterns within the basal ice. In the absence of meltwater filling a transverse channel, ice will deform into and fill it. If there is no exit from the channel, a flow separation will probably form between the main flow direction and the channel ice. The channel ice is likely to be relatively inactive, perhaps circulating slowly within the depression, (e.g. Gudmundsson's (1997) finite-element model of this process operating at a larger scale). However, if there is an exit to the channel, ice will flow from the high-stress, ice-entry area to the low-stress, outflow area, even at high angles to the main flow direction. Because creep rate increases as a function of ice thickness, highly variable basal ice flow could occur beneath all ice masses (i.e. at lower sliding velocities beneath thin ice, and at higher sliding velocities beneath thicker ice). At this stage, there appears to be little that can be interpreted with regard to ice dynamics from bedrock erosion features such as those described above.

\section{CONGLUSIONS}

Subglacial and proglacial observations from Øksfjordjøkelen and Konowbreen demonstrate that contemporaneous, locally highly variable, basal ice flow can occur at the base of temperate glaciers. Such ice flow can erode bedrock, and excavate channels. These channels have the potential to become smoothed if ice flow and abrasion persists along them. If fractures are aligned transverse to flow then the resultant form could be a transverse trough (Kor and others, 1991). Fracture 
lines, which are parallel or sub-parallel to the main ice-flow direction, may be smoothed and widened by basal ice erosion to produce furrows (Kor and others, 1991). Given a favourable bedrock structure (a joint striking at an oblique to high angle to the main basal ice-flow direction and intersecting the bedrock surface at a low angle), quarrying and abrasion could produce comma p-forms. The conditions for developing oblique ice flows may be met beneath a range of glaciers. Some p-forms are undoubtedly the product of subglacial fluvial erosion (e.g. potholes and spindle forms), especially when they are found in high densities (Shaw, 1988). However, the evidence presented in this paper suggests that this need not always be the case. Each p-form or group of p-forms should be examined carefully, especially if they contain glacial striations. If evidence of mechanical ice erosion is significant, then the form should not be considered solely as a product of fluvial erosion (Shaw, 1988; Kor and others, 1991), but at least as a polygenetic form.

\section{ACKNOWLEDGEMENTS}

Research in Spitsbergen was undertaken on the University of Glasgow Spitsbergen 1996 Expedition supported by the Carnegie Trust, the Gilchrist Educational Trust, the Royal Geographical Society, the Royal Scottish Geographical Society and the University of Glasgow. T. Dixon was in receipt of a School of Geosciences, Queen's University of Belfast, postgraduate studentship. Work in North Norway during 1997 was undertaken on the Queen's University of Belfast 1997 Øksfjordjøkelen Expedition. Thanks to D. Twigg for undertaking the bedrock surveying at Øksfjordjøkelen and to G. Alexander for producing the diagrams. Through the efforts of B. Hubbard, M. Hambrey, W. Harrison and an anonymous referee, this paper was significantly improved.

\section{REFERENCES}

Allen, J. R. L. 1971. Transverse erosional marks of mud and rock: their physical basis and geological significance. Sediment. Geol., 5, 167-384.

Boulton, G. S. 1974. Processes and patterns of glacial erosion. In Coates, D. R., ed. Glacial geomorphology. Binghamton, NY, State University of New York, 41-87.

Dahl, R. 1965. Plastically sculptured detail forms on rock surfaces in northern Nordland, Norway. Geogr. Ann., 47A(2), 83-140.
Demorest, M. 1938. Ice flowage as revealed by glacial striae. F. Geol., 46, $700-725$.

Edelman, N. 1949. Some morphological details of the roches moutonnées in the archipelago of SW Finland. Bull. Comm. Géol. Finl. 144, 129-137.

Gjessing, J. 1966. On 'plastic scouring' and 'subglacial erosion'. Nor. Geogr. Tidsskr., 20(1-2), 1965-1966, 1-37.

Goldthwait, R. P. 1979. Giant grooves made by concentrated basal ice streams. F. Glaciol., 23 (89), 297-307.

Gray, J. M. 1982. Unweathered, glaciated bedrock on an exposed lake bed in Wales. F. Glaciol., 28(100), 483-497.

Gray, J. M. and J. J. Lowe. 1982. Problems in the interpretation of smallscale erosional forms on glaciated bedrock surfaces: examples from Snowdonia, north Wales. Proc. Geol. Assoc., 93(4), 403-414.

Gudmundsson, G. H. 1997. Basal-flow characteristics of a linear medium sliding frictionless over small bedrock undulations. f. Glaciol., 43(143), 71-79.

Hallet, B. 1976. Deposits formed by subglacial precipitation of $\mathrm{CaCO}_{3}$. Geol. Soc. Am. Bull., 87 (7), 1003-1015.

Hallet, B. 1979. A theoretical model of glacial abrasion. F. Glaciol., 23(89), 39-50.

Hallet, B. 1981. Glacial abrasion and sliding: their dependence on the debris concentration in basal ice. Ann. Glaciol., 2, 23-28.

Harland, W. B. 1997. Central western Spitsbergen. In Harland, W. B., ed. The geology of Svalbard. London, The Geological Society, 154-178. (Memoir 17.)

Johnsson, G. 1956. Glacialmorfologiska studier i södra Sverige. Med särskild hänsyn till glaciala riktningselement och periglaciala frostfenomen. Medd. Lunds Univ. Geogr. Inst. Avh. 30.

Kor, P. S. G., J. Shaw and D. R. Sharpe. 1991. Erosion of bedrock by subglacial meltwater, Georgian Bay, Ontario: a regional view. Can. F. Earth Sci., 28(4), 623-642.

Ljunger, E. 1930. Spaltentektonik und Morphologie der schwedischen Skagerrak-Küste Teil III. Die Erosionsformen. Bull. Geol. Inst. Univ. Uppsala 21, 255-478.

Norsk Polarinstitutt. 1988. St. Fonsfjorden, Svalbard. (Scale 1:100,000.) Oslo, Norsk Polarinstitutt. (Geological Map of Svalbard B8.)

Rea, B. R. 1994. Plucking and abrasion beneath temperate plateau icefields. (Ph.D. thesis, Queen's University of Belfast.)

Rea, B. R. and W. B. Whalley. 1994. Subglacial observations from Øksfjordjøkelen, north Norway. Earth Surf. Processes Landforms, 19(7), 659-673.

Rea, B. R. and W. B. Whalley. 1996. The role of bedrock topography, structure, ice dynamics and preglacial weathering in controlling subglacial erosion beneath a high-latitude, maritime ice field. Ann. Glaciol., 22, 121-125.

Shaw, J. 1988. Subglacial erosional marks, Wilton Creek, Ontario. Can. f. Earth Sci., 25(8), 1256-1267.

Sheldon, P. 1926. Significant characteristics of glacial erosion as illustrated by an erosion channel. f. Geol., 34, 257-265.

Souchez, R., M. Lemmens and J. Chappellaz. 1995. Flow-induced mixing in the GRIP basal ice deduced from the $\mathrm{CO}_{2}$ and $\mathrm{CH}_{4}$ records. Geophys. Res. Lett., 22(1), 41-44.

Souchez, R., A. Bouzette, H. B. Clausen, S. J. Johnsen and J. Jouzel. 1998. A stacked mixing sequence at the base of the Dye 3 core, Greenland. Geophys. Res. Lett., 25(11), 1943-1946.

Sturt, B. A., I. R. Pringle and D. M. Ramsay. 1978. The Finnmarkian phase of the Caledonian Orogeny. 7. Geol. Soc. London, 135, 597-610. 